ks. Leonard Fic ${ }^{1}$

Uniwersytet kard. Stefana Wyszyńskiego

\title{
Wychowanie do dialogu międzyreligijnego podczas katechezy - wyzwanie współczesności
}

Przekazywanie rzetelnej i merytorycznej wiedzy na temat innych religii, ale również własnej, to nie tylko wymóg współczesnego pluralizmu religijno-kulturowego. To fundament, bez którego chrześcijanie nie będą w stanie przyjąć właściwej postawy wobec wyznawców innych religii, unikając takich skrajności jak powierzchowna i emocjonalna fascynacja innymi religiami i kulturami z jednej strony albo postawy wywyższania się, lekceważenia czy wręcz pogardy z drugiej². Pogłębiając własną tożsamość religijną, uczymy się szacunku wobec przedstawicieli innych religii. I odwrotnie, mając fachową i obiektywną wiedzę religioznawczą, jesteśmy w stanie bez konieczności rezygnacji z własnej tożsamości religijnej zaakceptować i w pełni uszanować religijną tożsamość ,innego”. Naturalną reakcją człowieka na to, czego nie zna i o czym nie ma pojęcia, są podejrzliwość, lęk, brak akceptacji, a nawet krytyka i jawna wrogość.

1 Ks. prof. dr hab. Leonard Fic - pracownik Uniwersytetu kard. Stefana Wyszyńskiego. Zajmuje się teologią fundamentalną, teologią dogmatyczną, religiologią (komparatystyka religii), religiami Indii i Dalekiego Wschodu (hinduizm, buddyzm, religie Chin i Japonii), dialogiem chrześcijaństwa z religiami pozachrześcijańskimi. E-mail: L.Fic@diecezja.wloclawek.pl.

2 I. S. Ledwoń, Chrześcijaństwo a religie pozachrześcijańskie, w: Byćchrześcijaninem. Teologia dla szkót średnich, red. M. Rusecki, Lublin 2006, s. 799. 
Stworzenie nowej kultury hermeneutycznej - „kultury uznania innych w swej inności", którą postuluje Johann Baptist Metz ${ }^{3}$, to wyzwanie dla pedagogiki spotkania, która ma ogromne znaczenie w procesie uczenia się postawy obowiązującej w dialogu międzyreligijnym, międzywyznaniowym czy międzykulturowym ${ }^{4}$.

Niniejszy artykuł jest próbą szkicowej prezentacji problematyki wychowania do dialogu międzyreligijnego jako palącego wyzwania, z którym musi się zmierzyć katecheza dzisiaj. Winno ono zmierzać w kierunku integralnego wychowania jej odbiorców (1), kształtowania ich właściwej postawy wobec wyznawców innych religii (2), otwarcia na dzieło ewangelizacji dialogicznej (3) i dialogu międzyreligijnego (4). Poniższe opracowanie jest jedynie skromnym zarysem wspomnianej wyżej ważnej współcześnie problematyki.

\section{Wychowanie integralne ${ }^{5}$}

Zgodnie z nauką Soboru Watykańskiego II wyrażoną w deklaracji Nostra aetate (O stosunku Kościoła do religii niechrześcijańskich) „ludzie oczekują od różnych religii odpowiedzi na głębokie tajemnice ludzkiej egzystencji, które jak niegdyś, tak i teraz do głębi poruszają ludzkie serca: czym jest człowiek, jaki jest sens i cel naszego życia, co jest dobrem, a co grzechem, jakie jest źródło i jaki cel cierpienia, na jakiej drodze można osiągnąć prawdziwą szczęśliwość, czym jest śmierć, sąd i wymiar sprawiedliwości po śmierci, czym wreszcie jest owa ostateczna i niewysłowiona tajemnica, ogarniająca nasz byt, z której bierzemy początek i ku której dążymy" ${ }^{\circ}$. Takie odejście od wertykalnego rozumienia religii i zdefiniowanie zjawiska religijnego bardziej na płaszczyźnie egzystencjalnej

3 J. B. Metz, H. E. Bahr, Augen für die Anderen, München 1991, s. 59, cyt. za: M. Jäggle, Międzykulturowo, międzyreligijnie, międzywyznaniowo, „Keryks” 1 (2002) nr 1, s. 178.

4 M. Jäggle, Międzykulturowo, międzyreligijnie, międzywyznaniowo, dz. cyt., s. 179 n.

5 Zob. M. Dziewiecki, Pedagogika integralna, Warszawa 2014.

6 Paweł VI, Deklaracja o stosunku Kościoła do religii niechrześcijańskich Nostra Aetate, 1 w: Sobór Watykański II, Konstytucje, dekrety, deklaracje, Poznań 2002, s. 334. 
niż teologicznej umożliwiło stronie katolickiej uwypuklenie tych cech, które są wspólne dla wszystkich systemów religijnych.

Świadomość chrześcijan, że wyznawcy innych religii mają tę samą potrzebę odkrywania sensu życia i że ich wiara ma także funkcję humanizującą w wychowaniu, otwiera drzwi do dialogu międzyreligijnego, do otwarcia się na „innego”, dla którego wartości duchowe są tak samo ważne jak dla wszystkich ludzi wierzących. Prawdziwy dialog rodzi się bowiem w momencie, gdy spotkanie z „innym” przeradza się w doświadczenie interpersonalne, w którym pojednanie różnorodności odbywa się poprzez budowanie przestrzeni obcowania z budzącym kontrowersje z powodu różnic drugim człowiekiem ${ }^{7}$. To właśnie różnice w poglądach i przyjmowanych wartościach kształtują wolność i tożsamość danej jednostki. Zatracanie tożsamości na rzecz niwelowania różnic między wyznawcami różnych religii wzmaga tylko niezrozumienie, zagubienie i chaos. Z tego względu, jak wskazuje Eugeniusz Sakowicz, „nauczyciele, wychowawcy, pedagodzy [...] mają wspomagać dzieci i młode pokolenia w odkrywaniu przez nie własnej tożsamości”, czyli byciu sobą. „Z człowiekiem bez tożsamości - tłumaczy dalej Sakowicz - (bez sumienia, bez twarzy, dwulicowym, wielolicowym, religijnym koniunkturalistą, politycznie poprawnym) można zrobić wszystko. Można go zniewolić ideologicznie" . Taki człowiek nigdy nie będzie w stanie postrzegać „innych” jako bliźnich. Zawsze będzie widział w „innym” jedynie obcego, gorszego, wroga, którego nie należy kochać, lecz którego należy się obawiać.

Integralne wychowanie religijne powinno zatem skupić się $\mathrm{w}$ pierwszej kolejności na ukazaniu tej wielkiej Miłości, która nie oznacza jedynie sympatii, ale jest niewyobrażalnym darem Ojca i Syna w jedności Ducha Świętego, darem, w którym Bóg pozwolił poznać się człowiekowi i wzywa go do udziału w nim ${ }^{10}$. Jan Paweł II nieustannie przypominał, że „człowiek nie może żyć bez miłości. Człowiek pozostaje dla siebie istotą

7 T. Pikus, Dialog religijny i jego obszary, „Warszawskie Studia Teologiczne” 20 (2007) 1, s. 232.

8 E. Sakowicz, Inny, ale nie obcy, cz. 1, „Oświata Mazowiecka” 10 (2010) nr 04/05, s. 24.

9 E. Sakowicz, Inny, ale nie obcy, cz. 1, dz. cyt., s. 24.

10 J. Bagrowicz, Edukacja religijna współczesnej młodzieży. Źródła i cele, dz. cyt., s. 251. 
niezrozumiałą, jego życie jest pozbawione sensu, jeśli nie objawi mu się Miłość, jeśli nie spotka się z Miłością, jeśli jej nie dotknie i nie uczyni w jakiś sposób swoją, jeśli nie znajdzie w niej żywego uczestnictwa. I dlatego właśnie Chrystus - Odkupiciel, jak to już zostało powiedziane, «objawia w pełni człowieka samemu człowiekowi». To jest ów - jeśli tak wolno się wyrazić - ludzki wymiar Tajemnicy Odkupienia. Człowiek odnajduje w nim swoją właściwą wielkość, godność i wartość swego człowieczeństwa. Zostaje on w Tajemnicy Odkupienia na nowo potwierdzony, niejako wypowiedziany na nowo. Stworzony na nowo!"11.

To właśnie takie ujęcie bezinteresownej miłości Boga do człowieka, które nie występuje poza chrześcijaństwem, wzywa chrześcijan do otwartości, szacunku, miłości, przyjaźni, a przede wszystkim do wykazania odrobiny dobrej woli w próbie zrozumienia i zaakceptowania praw do posiadania odmiennych podglądów przez drugiego człowieka. Perspektywa patrzenia na innych bez lęku i uprzedzeń realizować się może w pełni dopiero na drodze dialogu. Owa dialogika religii i kultur staje się dziś drogą umożliwiającą pokojowe współistnienie ludzi tworzących tzw. globalną wioskę (global vilage). Tylko w poszanowaniu prawa do wolności przekonań innych jednostka ludzka, bez potrzeby rezygnacji z własnej tożsamości religijno-kulturowej, może docenić, zrozumieć i zaakceptować naprawdę tożsamość „innego”. Domagając się szacunku dla własnej kultury, tradycji i tożsamości religijnej, winniśmy to samo okazywać innym. Dialog nie może bowiem stanowić jedynie wyrazu tolerancji, lecz musi rodzić taką sympatię, która łączy „zasadę poszanowania odmienności kulturowych z ochroną wspólnych wartości, z których nie wolno rezygnować, gdyż ich fundamentem są uniwersalne prawa człowieka"12. Chodzi zatem o taką empatię, używając słów Jacques’a Dupuis, która „pozwala zrozumieć «innych» tak, jak oni siebie rozumieją, a nie tak, jak my myślimy o nich, posługując się tradycyjnymi i uparcie trwającymi

11 Jan Paweł II, enc. Redemptor hominis, 10.

12 Zob. Jan Paweł II, O zachowanie własnej tożsamości i uznanie tożsamości innych. Orędzie Jana Pawła II na Światowy Dzień Migranta i Uchodźcy 2005 r., nr 3, „L’Osservatore Romano” (wyd. pol.) 26 (2005) nr 3 (271), s. 7. 
przesądami"13. Chodzi o poznanie drugiego człowieka w całym jego spektrum, o jego niezbywalne prawo do godności i wolności sumienia. Dialog to przecież proces pozytywnych i konstruktywnych stosunków między wyznawcami różnych religii, kultur i tradycji, którego celem jest chęć wzajemnego poznania i obopólnego wzbogacenia, bez konieczności rezygnacji z własnej tożsamości religijnej i wolności przekonań ${ }^{14}$.

\section{Pedagogika spotkania i pedagogika konfliktu}

Koniecznym warunkiem kształtowania się odniesienia chrześcijan do innych religii jest również znajomość dziejów relacji chrześcijaństwa do innych religii, które nie zawsze układały się bezkonfliktowo, co wynikało z braku odpowiedniej wiedzy, jak i z określonego kontekstu historyczno-doktrynalnego czy mentalności ludzi danej epoki historycznej. Znajomość historii relacji chrześcijaństwa z innymi religiami pozwala, jak zauważa Ireneusz S. Ledwoń, „uniknąć niejednego błędu popełnionego w przeszłości oraz zyskać odpowiednią mądrość niezbędną dla teraźniejszości i przyszłości"15. Edukacja religijna to wychowanie oparte nie tylko na wiedzy o człowieku, lecz przede wszystkim na wiedzy o wartościach, szczególnie etycznych i moralnych ${ }^{16}$. Wychowanie religijne współczesnej młodzieży powinno uwzględniać także nie tylko wartości płynące z miłości Boga do człowieka, lecz i te, które realizowane są w spotkaniu z drugim człowiekiem (miłość bliźniego), czego nauczał i co realizował w pełni Jezus Chrystus.

Niwelowanie różnic religijnych i kulturowych w dialogu sprzyja niestety tendencjom fundamentalistycznym. Stąd „ważnym przyczynkiem do przezwyciężenia trudności pedagogiki w wypowiadaniu się na temat religii w kontekście pluralizmu kulturowego i religijnego" jest konieczność uwzględniania kontekstu kulturowego, w którym dana religia

${ }_{13}$ J. Dupuis, Chrześcijaństwo i religie. Od konfrontacji do dialogu, przekł. S. Obirek, Kraków 2003, s. 33.

14 Por. T. Pikus, Dialog religijny i jego obszary, dz. cyt., s. 235.

15 I. S. Ledwoń, Chrześcijaństwo a religie pozachrześcijańskie, dz. cyt., s. 799.

16 J. Bagrowicz, Edukacja religijna współczesnej młodzieży. Źródła i cele, Toruń 2000, s. 66. 
powstała. Bez tego odniesienia katecheta nie będzie w stanie zaprezentować danej religii we właściwy sposób ${ }^{17}$. Cel międzyreligijnego uczenia się nie może być ograniczony jedynie do nauki religii, lecz musi uwzględniać przede wszystkim analityczny dyskurs wrażliwości religijnych różnic z pominięciem tendencji wartościujących ${ }^{18}$. Niemieccy teologowie podkreślają, że w edukacji religijnej to właśnie różnice między religiami powinny stać się punktem wyjścia i zadaniem dla szkolnego katechety ${ }^{19}$. Taka postawa nie zagraża bowiem budowaniu chrześcijańskiej tożsamości. Wręcz przeciwnie - tożsamość chrześcijańska, jak wskazuje Hans-Georg Ziebertz, „stanie się możliwa dopiero dzięki postrzeganiu różnic" ${ }^{20}$.

Z tego względu wielu niemieckich pedagogów chrześcijańskich twierdzi, że ów „pluralizm musi stać się tematem nauczania religijnego - taki pluralizm, który nie jest dobry sam w sobie, lecz którego różne możliwości mogą być godne pragnienia lub odrzucenia"21. Dzięki temu nauka o innych religiach na katechezie może odbywać się w formie pytań i pertraktacji. W ten sposób lekcja katechezy staje się sprawdzianem świętości, gdyż polega na przezwyciężaniu egocentryzmu i wyjściu do drugiego człowieka w postawie pełnego otwarcia się na jego „inność” w formie pytań i odpowiedzi ${ }^{22}$. Dialog międzyreligijny to przecież ważny element misji ewangelicznej Kościoła, którego celem nie jest ani chęć nawracania wyznawców innych religii na własną, ani próba tworzenia jakiejś wspólnej panreligii. Podstawowym celem jest przecież wzajemne poznanie, przezwyciężenie postawy zamknięcia wobec ,innych”, pokonanie uprzedzeń. Następnie chodzi o poszukiwanie prawdy, która przecież może być obecna także w religii partnera dialogu. To wzajemne wzbogacenie uczestników dialogu umożliwia pogłębienie własnej wiary, a nawet nowe spojrzenie na własną religię i religię interlokutora ${ }^{23}$.

\footnotetext{
17 M. Jäggle, Międzykulturowo, międzyreligijnie, międzywyznaniowo, dz. cyt., s. 182.

18 M. Jäggle, Międzykulturowo, międzyreligijnie, międzywyznaniowo, dz. cyt., s. 184.

19 M. Jäggle, Międzykulturowo, międzyreligijnie, międzywyznaniowo, dz. cyt., s. 175.

20 M. Jäggle, Międzykulturowo, międzyreligijnie, międzywyznaniowo, dz. cyt., s. 176.

${ }_{21}$ M. Jäggle, Międzykulturowo, międzyreligijnie, międzywyznaniowo, dz. cyt., s. 177.

22 I. S. Ledwoń, Chrześcijaństwo a religie pozachrześcijańskie, dz. cyt., s. 808.

23 I. S. Ledwoń, Chrześcijaństwo a religie pozachrześcijańskie, dz. cyt., s. 809.
} 
Kościół katolicki w soborowej deklaracji Nostra aetate wyraźnie podkreśla, iż uznaje pozytywne wartości i zbawcze elementy obecne w judaizmie, islamie, hinduizmie, buddyzmie oraz w religiach pierwotnych czy religiach typu aniministycznego. Przypomina, że „,nie odrzuca z tego, co w religiach owych prawdziwe jest i święte". Że szanuje wszystkie odmienne sposoby działania i życia oparte na nakazach i doktrynach innych niż chrześcijaństwo. Odwołując się natomiast do istnienia we wszystkich religiach niechrześcijańskich tzw. semina Verbi („nasiona Słowa”), zachęca chrześcijan do wspólnego poszukiwania z wyznawcami innych religii promieni „owej Prawdy, która oświeca wszystkich ludzi”"24.

W praktyce niestety nie zawsze chrześcijanie potrafią zachować właściwą postawę wobec wyznawców innych religii. Wynika to przede wszystkim z braku elementarnej wiedzy na temat doktryn, wartości i nakazów kulturowych, którymi w życiu kierują się przedstawiciele innych religii. Magdalena Rzym w artykule Trudna miłość, poświęconym postawie katolików wobec innych religii w Polsce, podkreśla, że postawę sprzeczną z oficjalnym stanowiskiem Kościoła często prezentują sami katolicy, zwłaszcza ci, którzy często goszczą w mediach publicznych. Zdaniem autorki brak wiedzy, uproszczony przekaz medialny i uprzedzenia potęguja wśród katolików nieuzasadniony lęk przed wyznawcami innych religii ${ }^{25}$. Główny problem tkwi w demonizowaniu innych religii i uznawaniu jakiegokolwiek kontaktu z nimi za niebezpieczny ${ }^{26}$. Błąd polega na tym, że problematyka tematyki dialogu ekumenicznego i międzyreligijnego nie może być sprowadzona do problematyki przeciwdziałania zjawiskom pseudoreligijnym (herezje, sekty, magia, okultyzm, ezoteryka, praktyki New Age). Niebezpieczeństwo i powstanie wątpliwości rodzi np. stawianie Koranu na równi z Biblią satanistyczną i traktowanie ich jako ksiąg służących bałwochwalczemu kultowi. Postawie dialogicznej nie sprzyja również demonizowanie wywodzących się z buddyzmu, hinduizmu,

24 Paweł VI, dekl. Nostra etate, 2.

25 M. Rzym, Trudna miłość. Katolicy wobec innych religii, „Misyjne Drogi” 34 (2016) nr 5/179, s. 55.

${ }^{26}$ M. Rzym, Trudna miłość. Katolicy wobec innych religii, dz. cyt., s. 55. 
islamu technik medytacyjnych, których praktykę postrzega się jedynie jako techniki ruchu New Age, które zniewalają mocą szatana.

Za absurdalne i sprzeczne ze stanowiskiem Kościoła należy uznać również wypowiedzi znanego w mediach dziennikarza, podróżnika i publicysty Wojciecha Cejrowskiego, który w jednym z odcinków telewizyjnego cyklu „Boso przez Świat”, emitowanego przez TVP (od czerwca 2011 przez TVN Style jako „Wojciech Cejrowski Boso”), stwierdził, że „buddyzm to religia bez Boga, za to z demonami”, że „turyści klękający przed pomnikami to głupi ludzie”, że „w buddyzmie czci się i oswaja demony, stosuje techniki okultystyczne, a chińskie wróżby wykłada w świątyni po to, by przyciągnąć prosty ludek”, że „Dalajlama co dzień modli się do Lucyfera - pana ciemności - o to, by ocalił wyznawców buddyzmu, a w zamian za to pochłonął innych, niewiernych, czyli nas". Program ten wywołał tak wielkie oburzenie, że publiczna telewizja zrezygnowała z jego dalszej emisji. Na fali krytyki sam autor tłumaczył się później w internecie: „Jedyna kwestia, która pochodziła bezpośrednio ode mnie, to słowa «głupie ludzie». Zostały wypowiedziane o katolikach (polska wycieczka za moimi plecami), a nie o buddystach. Skomentowałem głupie zachowanie moich braci w wierze - mam do tego prawo, a nawet mam taki obowiązek jako współwyznawca. Głupie ludzie, skoro najpierw idą na pielgrzymkę do Częstochowy, a teraz dookoła stupy" - tłumaczył Cejrowski. Być może demonizowanie buddyzmu nie było zamierzeniem autora filmu, jednak powstał medialny chaos, który wzbudził w widzach niepotrzebny niepokój, lęk i niechęć do buddystów. Przecież w zwiedzaniu przez katolików świątyń buddyjskich nie ma nic złego, jeśli nie wykonują oni czynności kultycznych. Sam papież Jan Paweł II podczas swojego pontyfikatu wielokrotnie odwiedzał żydowskie synagogi, muzułmańskie meczety, klasztory buddyjskie czy hinduskie świątynie.

Kolejnym przykładem głoszenia nauki sprzecznej z oficjalnym stanowiskiem Kościoła katolickiego są wypowiedzi o islamie, którego wyznawców często utożsamia się z terrorystami, dążącymi przemocą do islamizacji Europy. Taki obraz islamu prezentuje m.in. katolicki dziennikarz Tomasz Terlikowski (2016) w opublikowanej niedawno książce Kalifat Europa. Można w niej wyczytać, że islam jest religią skazującą swoich wyznawców na życie w zniewoleniu duchowym, ma źródła 
satanistyczne, a ISIS jest właściwym obliczem islamu, a nie jedynie jego wypaczeniem $^{27}$. Na katolickich forach internetowych aż roi się od negatywnych komentarzy na temat prowadzonego przez Kościół dialogu. Niechęć, stereotypy, a nawet wrogość do przedstawicieli innych religii ze strony samych katolików powinny uświadomić pedagogom, jak ważna i potrzebna jest ewangelizacja dialogiczna, polegająca na rzetelnym przekazywaniu wiedzy na temat innych i środowiska kulturowego, w jakim powstały.

\section{Otwarcie katechezy na ewangelizację i dialog międzyreligijny: model konfesyjno-dialogiczny}

Od lat czterdziestych XX wieku nauczanie katechezy zdominował model kerygmatyczny (konfesyjno-katechumenalny), sprowadzający działalność dydaktyczną do przesłanek teologicznych, zwiastowania Dobrej Nowiny, wzywania do dawania świadectwa prawdzie chrześcijańskiej oraz wprowadzania katechizowanych w życie Kościoła ${ }^{28}$. Podstawowym źródłem nauczania młodzieży przyjętym w tym modelu są Pismo Święte, teksty liturgiczne i dokumenty Kościoła. Misją katechety jest przekazywanie treści teologicznych w ujęciu kerygmatycznym (wyznaniowym). Wraz z przemianami społeczno-kulturowymi młodzież wysunęła zarzut pod adresem tak prowadzonej katechezy, która ich zdaniem nie powinna być narzucaniem z góry jakiegoś modelu wiary bez współudziału odbiorcy, który jest znacznie bardziej niż kiedyś uwrażliwiony na współpracę i uszanowanie jego wolności przekonań ${ }^{29}$. Język katechezy zakorzeniony w terminologii teologicznej daleki jest także od języka, którym katechizowani posługują się na co dzień, jest daleki od ich doświadczeń. Nie chodzi oczywiście o to, aby rezygnować z Biblii, ale o to, aby do młodych ludzi mówić takim językiem, który przybliży im orędzie biblijne ${ }^{30}$.

\footnotetext{
T. Terlikowski, Kalifat Europa, Kraków, 2016.

J. Bagrowicz, Edukacja religijna wspótczesnej młodzieży. Źródła i cele, dz. cyt., s. 276.

29 J. Bagrowicz, Edukacja religijna współczesnej młodzieży. Źródła i cele, dz. cyt., s. 278.

30 J. Bagrowicz, Edukacja religijna współczesnej młodzieży. Źródła i cele, dz. cyt., s. 278.
} 
Współczesny pluralizm kulturowy i religijny na Zachodzie rodzi konieczność wypracowania nowej koncepcji edukacji religijnej w duchu bardziej ekumenicznym, otwartym na zrozumienie i tolerancję wobec przedstawicieli innych niż katolicka religii i kultur ${ }^{31}$. Przecież w ramach samego chrześcijaństwa istnieje wiele nurtów, doktryn i obrządków, a także form organizacyjno-instytucjonalnych. Wyznawcy różnych religii żyją w tym samym środowisku co katolicy. Jak zatem w takim multikulturowym środowisku powinna wyglądać dziś lekcja katechezy? Najważniejszym wyzwaniem edukacji religijnej, na które zwraca uwage Eugeniusz Sakowicz, jest to, aby „ludzie żyjący w przestrzeniach różnorodności kulturowej zdobywali wiadomości na temat swoich religii i relacji między nimi" 32 . Wzajemnie poznanie się toruje bowiem drogę do tzw. nauczania międzyreligijnego, „którego przedmiotem jest problematyka różnych religii świata, a celem motywowanie, kształtowanie i w końcu wyrobienie w uczniu aktywnego stosunku do własnej religii oraz do innego systemu wierzeń" ${ }^{33}$. Dzięki merytorycznej wiedzy na temat innych religii uczeń staje się nie tylko odpowiedzialnym wyznawcą własnej wiary, lecz również w sposób odpowiedzialny potrafi wchodzić w dialog z wyznawcami innych religii i przedstawicielami innych kultur. „Międzyreligijne nauczanie - zdaniem Sakowicza - może być również rozumiane jako część szeroko pojętego dialogu międzyreligijnego, będącego komunikacją interpersonalną ludzi wyznających różne religie. Osoby uczestniczące $\mathrm{w}$ procesie tego nauczania wzajemnie poznają się, zaznajamiają z doktryną oraz etyką określonego systemu wierzeń, a także podejmują wspólne działania na rzecz promocji wartości ogólnoludzkich (np. pokoju, tolerancji, solidarności społecznej)" ${ }^{34}$. Interreligijne doświadczenie pozawala bowiem dostrzec zarówno różnice między religiami, również w przypadku tych monoteistycznych (judaizm, chrześcijaństwo, islam), jak i szereg podobieństw. Pozwala na zachowanie własnej

31 J. Bagrowicz, Edukacja religijna wspótczesnej młodzieży. Źródła i cele, dz. cyt., s. 275.

32 E. Sakowicz, Edukacja w środowisku pluralizmu kulturowego i religijnego, w: Kultura - młodzież-edukacja, red. A. Popławska, L. M. Jakoniuk, Białystok 2008, s. 283.

33 E. Sakowicz, Edukacja w środowisku pluralizmu kulturowego i religijnego, dz. cyt., s. 284.

34 E. Sakowicz, Edukacja w środowisku pluralizmu kulturowego i religijnego, dz. cyt., s. 284. 
tożsamości, bez konieczności szukania jakiegoś wspólnego mianownika, który jednoczyłby wszystkich wyznawców w ramach jakieś jednej panreligii ${ }^{35}$.

Najważniejsze wyzwanie dla pedagogów katolickich stanowi otwarcie katechezy na ewangelizację, a więc na potrzeby młodych ludzi, którzy poszukują własnej drogi i miejsca w życiu. Chodzi zatem o wypracowanie takiego modelu katechezy, który uwzględniałby „potrzebę wychowania młodzieży do dialogu, tolerancji, spotkania z przedstawicielami innych religii i wyznań - czyli w duchu ekumenicznym"36. Trudno jednak, zdaniem prof. Jerzego Bagrownicza, stworzyć taki jeden model katechezy, który zawierałby w sobie zarówno wymogi zawarte w dokumentach Kościoła, jak i wymogi pedagogiczno-dydaktyczne multikulturowego środowiska katechizowanej młodzieży. W opinii autora najbliższym modelem, który mógłby spełnić te wymagania, jest „zaproponowany przez pedagogikę ewangelicką model nazywany konfesyjno-dialogicznym", stanowiący niejako kompromis pomiędzy modelami konfesyjno-katechumenalnym i ponadkonfesyjnym ${ }^{37}$. Przejęcie bowiem przez Kościół współodpowiedzialności za edukację prowadzoną w duchu otwarcia i dialogu staje się jednocześnie znakiem jego wiarygodności wobec świata ${ }^{38}$.

Nauczanie religijne powinno więc stać się w przyszłości tzw. „,bezinteresowną pedagogiką religijną", która oprócz celów bliskich wyznaniom realizuje cele ogólnospołeczne czy ogólnokulturowe. Przybliżanie dzieciom i młodzieży Ewangelii, szczególnie tym, które wychowane są bez chrześcijańskiej wizji świata, umożliwi zapoznanie się z najważniejszymi naukami Jezusa Chrystusa. Zadaniem takiej lekcji religii jest ukazanie zasad Ewangelii jako narzędzia krytycznej oceny rzeczywistości i podstawy do dokonywania własnych wyborów życiowych. Kościół jest bowiem wezwany do służby humanizacji ludzi, ich kultur i religii ${ }^{39}$.

\footnotetext{
E. Sakowicz, Edukacja w środowisku pluralizmu kulturowego i religijnego, dz. cyt., s. 285.

J. Bagrowicz, Edukacja religijna współczesnej młodzieży. Źródła i cele, dz. cyt., s. 283.

J. Bagrowicz, Edukacja religijna współczesnej młodzieży. Źródła i cele, dz. cyt., s. 283.

J. Bagrowicz, Edukacja religijna współczesnej młodzieży. Źródła i cele, dz. cyt., s. 284.

J. Bagrowicz, Edukacja religijna wspótczesnej młodzieży. Źródła i cele, dz. cyt., s. 285.
} 
Odnosząc się do innych religii, katecheta powinien w pierwszej kolejności kierować się w swoim życiu bardzo konkretnymi regułami tzw. Dekalogu dialogu międzyreligijnego:

1. Kształtowanie świadomości, że wszyscy ludzie, bez względu na wyznawaną religię, są dziećmi jednego Boga - Ojca i Stwórcy.

2. Ludzie innych religii mają prawo żyć obok siebie.

3. Jezus Chrystus zjednoczył się również z ludźmi innych religii poprzez wcielenie, mękę i zmartwychwstanie.

4. Duch Święty jest w tajemniczy sposób obecny w różnych kulturach i religiach niechrześcijańskich.

5. Poprzez coraz lepsze poznanie własnej religii mogę lepiej poznawać innych. Nie boję się mówić o tym, kim jestem i co wyznaję.

6. Bycie otwartym, wyrozumiałym i solidarnym z tym, co ludzkie, z wyznawcą każdej religii.

7. Nie myślę stereotypami ani nie wywyższam się w rozmowie z drugim człowiekiem.

8. Dzięki empatii rozmawiam z drugim człowiekiem tak, jak sam bym chciał, aby on ze mną rozmawiał. Słucham go tak samo, jak ja bym chciał zostać wysłuchany.

9. Pamiętam, że najważniejszym celem dialogu międzyreligijnego jest zbliżenie się do Boga - jedynej Prawdy, Drogi i Życia.

10. Pamiętam, że dialog międzyreligijny jest realizacją w codziennym życiu miłości Boga i bliźniego ${ }^{40}$.

\section{Prawda i dialog na katechezie}

Modernizacja społeczeństw nie spowodowała gwałtownej sekularyzacji, lecz raczej pluralizację religijności, polegającą na powstaniu coraz to nowych, często niezinstytucjonalizowanych form duchowości ${ }^{41}$. Zjawisko hybrydyzacji religii jest rezultatem wyizolowania z różnych re-

40 E. Sakowicz, Inny, ale nie obcy, cz. 2, „Oświata Mazowiecka” 02 (2011) nr 01 (06), s. 24.

${ }^{41}$ A. Różańska, Religijność młodzieży a pluralistyczne społeczeństwo czeskie na początku XXI wieku, w: Edukacyjny potencjał religii, red. J. Bagrowicz, J. Horowski, Toruń 2012, s. 316. 
ligii idei religijnych, z których ludzie konstruują swoją własną, prywatną religię̨2 . Ów subiektywny pogląd na wiarę i religijność, często niespójny i niezgodny z oficjalną nauką Kościoła, młodzież spycha do sfery prywatnej, i raczej o nim nie dyskutuje. Wobec wybiórczej akceptacji prawd i zasad wiary dialog międzyreligijny jako element misji ewangelizacyjnej Kościoła winien być prowadzony z szacunkiem, miłością, otwartością na partnera dialogu, braterstwem i szczerością, pokorą i poszanowaniem wolności drugiego człowieka ${ }^{43}$.

Powstaje jednak pytanie: Czy katecheza jest odpowiednim miejscem do dialogu czy przekazu prawdy objawionej? ${ }^{44}$. Wychowanie do dialogu na katechezie wskazuje bowiem na konieczność podejmowania dialogu między katechizującym i katechizowanym. Przecież wniknięcie w tajemnicę chrześcijańskiej wiary może odbywać się nie tylko poprzez jednostronny wykład, lecz również na drodze rozmowy, poprzez pytania i odpowiedzi. Przy czym należy pamiętać, że katecheza nie może przybierać tylko formy stale poszukującego dialogu. Prawda głoszona na katechezie ma swój ściśle określony cel - nawrócenie i prowadzenie do komunii z Chrystusem i Kościołem. Tej funkcji nie może zastąpić ani osłabiać dialog, który - by był prawdziwy - musi służyć przekazywaniu i głoszeniu tej prawdy. Jednocześnie, co podkreśla Mieczysław Polak, „prawda i dialog nie wykluczają się wzajemnie, gdyż dialogiczna komunikacja nie musi zawsze prowadzić do ostatecznego odkrycia prawdy. Już samo uwrażliwienie na prawdę, szczere pragnienie odkrywania prawdy i wola przylgnięcia do niej, chęć służenia jej jest wielką lekcją przygotowującą do dialogu. Samo też dążenie do prawdy jest już w pewnym sensie jej odkrywaniem. Dlatego w wychowaniu do dialogu istotne jest kształtowanie postawy otwartości, wzbudzanie pragnienia poznawania prawdy" ${ }^{45}$.

42 A. Różańska, Religijność młodzieży a pluralistyczne społeczeństwo czeskie na początku XXI wieku, dz. cyt., s. 326.

43 I. S. Ledwoń, Chrześcijaństwo a religie pozachrześcijańskie, dz. cyt., s. 809.

${ }_{44}$ M. Polak, Wychowanie do dialogu w katechezie młodzieży, „Studia Oecumenica” (2015) 15 , s. 414.

45 M. Polak, Wychowanie do dialogu w katechezie młodzieży, dz. cyt., s. 415. 
Z tego względu w opinii Jerzego Bagrowicza ${ }^{46}$ szkolna katecheza to właściwie miejsce wychowywania do postawy dialogu. „Najpierw są one właściwym środowiskiem kształtowania świadomości własnej tożsamości. Następnie dostarczają wielu istotnych wiadomości z zakresu wiedzy o zróżnicowaniu kulturowym i religijnym, o potrzebie dialogu międzyreligijnego i międzywyznaniowego. Coraz częstsze kontakty z wyznawcami innych religii czy wyznań religijnych stają się okazją do zdobywania umiejętności dialogu i tolerancji. Wychowanie do dialogu i tolerancji jest przecież istotnym elementem wychowania młodych, realizowanego w szkole, tym bardziej w szkolnej lekcji religii czy na katechezie" ${ }^{47}$.

Do tej pory w programach nauczania religii w szkole podstawowej, gimnazjum czy liceum uwzględniano już tematy z zakresu religioznawstwa i dialogu międzyreligijnego. W klasach I-III katecheza dialogu obejmuje takie tematy,jak: pragnienie szczęścia dla wszystkich mieszkańców ziemi, interpretacja pojęcia „bliźniego”, eklezjologiczne prośby o jedność i pokój wśród chrześcijan (ekumenizm), pragnienie jedności i pokoju między ludźmi na świecie (dialog międzyreligijny i międzykulturowy). W klasach IV-VI wychowanie do dialogu z innymi religiami odbywa się poprzez poruszanie takich ścieżek tematycznych, jak: odnajdywanie śladów Boga we współczesnym świecie, poszukiwanie wspólnych wartości stanowiących fundament wszystkich międzyludzkich relacji, pojęcie jedności

${ }^{46}$ „Ks. prof. Jerzy Bagrowicz (ur. 1938) zajmuje się problematyką z zakresu pedagogiki religii i katechetyki, a zwłaszcza uwarunkowaniami przekazu religijnego, humanistycznymi i biblijno-teologicznymi podstawami edukacji religijnej, edukacją religijną młodzieży, wychowaniem do dialogu i tolerancji oraz problematyką z zakresu katechetyki fundamentalnej. Dorobek naukowy ks. prof. Jerzego Bagrowicza obejmuje wiele opracowań naukowych, w tym 5 pozycji książkowych, współautorstwo 6 podręczników, redakcję licznych prac zbiorowych, artykuły i rozprawy w pracach zbiorowych, hasła w Encyklopedii katolickiej oraz Encyklopedii PWN Religia, artykuły w czasopismach pedagogicznych i teologicznych, redakcję naukową 101 zeszytów dwumiesięcznika naukowo-pastoralnego «Ateneum Kapłańskie», redakcję 20 tomów periodyku «Paedagogia Christiana», liczne referaty na sympozjach i konferencjach naukowych, także zagranicznych”. Cyt. za: Życiorys Księdza Profesora Jerzego Bargrowicza, „Paedagogia Christiana” 1/21 (2008), s. 13.

47 J. Bagrowicz, Towarzyszyć wzrastaniu. Z dyskusji o metodach i środkach edukacji religijnej młodzieży, Toruń 2006, s. 247, cyt. za: M. Polak, Wychowanie do dialogu w katechezie młodzieży, dz. cyt., s. 415-416. 
międzyludzkiej w ramach jedności eucharystycznej. Na poziomie gimnazjum tematyka dialogu religijnego zostaje poszerzona o następujące zagadnienia: wielość religii, wielkie religie świata, religie naturalne, trzy wielkie religie monoteistyczne, istota religii i uzasadnienie jej istnienia, przyczyny istnienia wielu religii, podziały wewnątrz Kościoła (ekumenizm). Na poziomie liceum profilowanego i szkoły zawodowej w programie katechezy pojawia się najpełniejsze rozwinięcie dialogu religijnego: religie i dialog z nimi („świat szuka Boga”), tolerancja religijna, wojny religijne i konflikty na podłożu religijnym („odpowiedzialność za świat”), prawo chroniące religie w systemie prawnym, kultura innych religii, religie Wschodu, islam, tolerancja w Polsce, przenikanie się religii i kultur, pogłębienie wiedzy o ateizmie i nowych ruchach religijnych ${ }^{48}$.

Przekaz prawdy metodą dialogu na katechezie do młodzieży nie powinien zawężać się do opanowania metod i technik dialogu, lecz winien prowadzić do kształtowania duchowości i kultury dialogu. „Znajomość czy nawet opanowanie metod lub technik dialogu - na co zwraca uwage Polak - nie zapewnią ukształtowania postawy dialogu, gdyż ta wymaga właściwej duchowości, mentalności czy kultury dialogu" ${ }^{49}$. Dopiero wtedy tak rozumiana pedagogika dialogu może stać się narzędziem umożliwiającym wykształcenie w młodym pokoleniu takich predyspozycji, jak: uczciwość, szczerość, prawdomówność, cierpliwość, roztropność, rzetelność, delikatność, zdolność podejmowania wyrzeczeń i skłonność do podjęcia pracy nad sobą. Wychowując młodego człowieka ku postawie dialogicznej, będziemy mieć pewność, że podejmując dialog z wyznawcami innych religii, będzie on w stanie wyjść poza swoje ograniczenia, zwłaszcza natury emocjonalnej, jak nieśmiałość, podejrzliwość, nieufność czy lęk $\mathrm{k}^{50}$.

Oprócz wychowywania do właściwej postawy dialogicznej katecheta powinien również potrafić w rzetelny sposób przekazać młodym ludziom wiedzę na temat innych religii. Przygotowując tematy katechezy

48 Por. E. Sakowicz, Edukacja w środowisku pluralizmu kulturowego i religijnego, dz. cyt., s. $288-289$.

49 M. Polak, Wychowanie do dialogu w katechezie młodzieży, dz. cyt., s. 418.

50 Por. M. Polak, Wychowanie do dialogu w katechezie młodzieży, dz. cyt., s. 420. 
poświęcone religiom niechrześcijańskim ${ }^{51}$, nie może ograniczać się do korzystania z opracowań, zwłaszcza tych, które pisane są w tonie chrześcijańskiej apologetyki. W pierwszej kolejności powinien bazować na tekstach źródłowych oraz na fachowej literaturze przedmiotu, zwłaszcza na tej, która ukazuje się nakładem wydawnictw uniwersyteckich. Dzięki temu katecheta będzie miał pewność, że przekazywana przez niego wiedza na temat nakazów religijnych, wartości etycznych czy filozofii danego systemu wierzeń będzie wiedzą jak najbardziej obiektywną. W wychowaniu do dialogu międzyreligijnego to merytoryczna, fachowa i rzetelna wiedza na temat innych religii zapewnia ten fundament, na którym zasadza się prawdziwy dialog. Obiektywizm z zakresu religioznawstwa jest bowiem w stanie uchronić uczestników dialogu przed skutkami relatywizmu, synkretyzmu, irenizmu czy fundamentalizmu religijnego. Poznając różnice między religiami, jesteśmy w stanie bez utraty własnej tożsamości religijnej otworzyć się na poznanie i zrozumienie partnera dialogu. Jesteśmy w stanie bez lęku uszanować jego niezbywalne prawo do wolności wyznania. Jesteśmy w stanie zadawać pytania i sami odpowiadać zgodnie z tym, kim jesteśmy. „Predyspozycje moralne kształtowane podczas katechezy dają podstawy do właściwych relacji międzyludzkich, budowanych na uznaniu równej godności wszystkich

51 Przykład prezentacji cyklu katechetycznego: Wielkie religie współczesnego świata: kultura - spotkanie - dialog (judaizm, islam, hinduizm, buddyzm). Materiały źródłowe - dostępne w języku polskim: judaizm: Tora (Pięcioksiąg Mojżeszowy), Talmud (Miszna i Gemara), Stary Testament (Septuaginta); islam: Koran, Sunna, Hadisy; hinduizm: wedyjska literatura objawiona (śruti) - Wedy (Rygweda, Jadźurweda, Samaweda, Atharwaweda), Brahmany, Aranjaki, Upaniszady - tradycja wedyjska (smryti) Mahabharata i Ramajana, samodzielna Bhagawadgita; buddyzm: sutty (sutry) wywodzące się z kanonu Tipitaka („Trójkosz”) - Vinaja-pitaka („Kosz reguł zakonnych”), Sutta-pitaka („Kosz nauk”), Abhidhamma-pitaka („Kosz dodatkowej nauki” - Abhidhammy). Katecheza może przebiegać według poniższego schematu:

rys historyczny danej religii (tło historyczne powstania, osoba założyciela, ewolucja w historii); ków);

treść religijna (święte księgi, podstawowe prawdy wiary, charakterystyka symboli i zna-

istota życia religijnego (modlitwa, miejsca kultu, etyka i wskazania moralne);

współczesne oblicze tej religii (jej wpływ na kształtowanie się danego społeczeństwa, jakich wartości można się uczyć od jej wyznawców, co wnosi do kultury danej społeczności);

praca z tekstami źródłowymi;

dyskusja w formie pytań i odpowiedzi. 
ludzi, na wzajemnym szacunku, na wolności, a ostatecznie na chrześcijańskiej miłości obejmującej nawet nieprzyjaciół"52. Praca z tekstami źródłowymi „daje duże możliwości do poznania treści zarówno własnej wiary, jak i innych religii” ${ }^{53}$.

Do tej pory kształtowanie odniesienia do innych religii w programie katechezy miało, co podkreśla Polak, „charakter bardziej apologetyczny i polemiczny niż dialogiczny”, gdyż prezentowane treści i wymagania miały „na celu raczej obronę katolickiej wiary niż uzdolnienie do dialogu" ${ }^{54}$. Z tego względu największym zadaniem dla współczesnej pedagogiki chrześcijańskiej jest nauczanie katechezy w duchu soborowej Deklaracji Nostra aetate ${ }^{55}$. Wychowanie do dialogu uczy nie tylko realistycznego myślenia, lecz przede wszystkim kształtuje w młodym człowieku postawę otwartości i szacunku względem przedstawicieli innych religii, a także osób niewierzących. Wychowanie do dialogu wymaga również odwagi w zachowaniu własnej tożsamości religijnej, w byciu autentycznie sobą. Dialog to bowiem nie kompromis, lecz dążenie do uznania innych w swej inności. To określanie chrześcijańskiej tożsamości nie poprzez niwelowanie różnic, lecz uświadamianie ich sobie i uszanowanie ich istnienia bez konieczności wartościowania i oceniania.

\footnotetext{
M. Polak, Wychowanie do dialogu w katechezie młodzież, dz. cyt., s. 421.

M. Polak, Wychowanie do dialogu w katechezie młodzież, dz. cyt., s. 421.

M. Polak, Wychowanie do dialogu w katechezie młodzież, dz. cyt., s. 424.

55 Zob. J. Bagrowicz, Nostra aetate - wyzwanie dla pedagogii chrześcijańskiej, „Collectanea Theologica" 76 (2006), z. 2, s. 7-26.
} 


\section{Summary}

\section{Kształtowanie odniesienia do innych religii na katechezie - wyzwanie współczesności}

Chrześcijanie żyją w świecie coraz bardziej otwartym. Zarazem powszechna dostępność mediów, turystyka oraz nowe ruchy migracyjne sprzyjają kontaktom z wyznawcami innych religii. Dziś w wychowaniu katolickim coraz bardziej potrzeba wychowania do rozumienia i dialogu z innymi religiami. Najważniejszym zadaniem pedagogiki religijnej jest nauczanie katechezy w duchu deklaracji Nostra aetate. Takie wychowanie powinno kształtować w młodym człowieku postawę otwartości i szacunku względem przedstawicieli innych religii, a także osób niewierzących. Wychowanie do dialogu wymaga też zachowania własnej autentyczności religijnej, a nie rezygnowania z niej. Dialog to dążenie do uznania innych w ich inności. Kształtowanie autentycznych postaw wobec przedstawicieli innych religii wśród młodzieży katolickiej wymaga od katolickich nauczycieli poznania innych religii i pewnego wysiłku intelektualnego służącego obiektywnemu przedstawieniu innych religii. Wraz z tym powinien dokonywać się wysiłek dydaktyczny wspomagający akceptację własnej religijności.

Słowa kluczowe: wychowanie religijne, katecheza, pedagogika dialogu

\section{Shaping the Attitude Towards Other Religions During Catechesis/Religious Education - the Challenge of the Present Times}

Christians live in an increasingly open world. The widespread availability of media, tourism, and new migration movements taken together favour Christians' contacts with followers of other religions. The need for education to understand and communicate with other religions is more necessary now than ever before in Catholic education. The most important task of religious pedagogy is to teach catechesis/religious education in the spirit of the declaration Nostra aetate. Such education should shape a young person's attitude of openness and respect towards representatives of other religions, as well as towards non-believers. Educating to communicate with others also requires the preservation of religious authenticity, not renouncing it. The dialogue/the communication is the desire to recognize others in their own way. Forming authentic attitude towards other religions representatives among young Catholics requires from Catholic teachers to know other religions and it requires some intellectual effort which serves to present other religions in an objective way. The didactic effort to support the acceptance of one's own religiosity should also be made along with it.

Keywords: religious education, catechesis, pedagogy of dialogue, communication 


\section{Bibliografia}

Bagrowicz J., Edukacja religijna wspótczesnej młodzieży. Źródła i cele, Toruń 2000.

Bagrowicz J., Towarzyszyć wzrastaniu. $Z$ dyskusji o metodach i środkach edukacji religijnej młodzieży, Torun 2006.

Być chrześcijaninem. Teologia dla szkót średnich, red. M. Rusecki, Lublin 2006.

Dupuis J., Chrześcijaństwo i religie. Od konfrontacji do dialogu, przekł. S. Obirek, Kraków 2003.

Edukacyjny potencjał religii, red. J. Bagrowicz, J. Horowski, Torun 2012.

Jäggle M., Międzykulturowo, międzyreligijnie, międzywyznaniowo, „Keryks” 1 (2002) nr 1, s. 175-186.

Jan Paweł II, Encyklika Redemptor hominis.

Jan Paweł II, O zachowanie własnej tożsamości i uznanie tożsamości innych. Orędzie Jana Pawła II na Światowy Dzień Migranta i Uchodźcy 2005 r., „L'Osservatore Romano” (wyd. pol.) 26 (2005) nr 3 (271), s. 7-8.

Kultura - młodzież-edukacja, red. A. Popławska, L. M. Jakoniuk, Białystok 2008.

Ledwoń I. S., Chrześcijaństwo a religie pozachrześcijańskie, w: Być chrześcijaninem. Teologia dla szkót średnich, red. M. Rusecki, Lublin 2006, s. 799-825.

Paweł VI, Deklaracja o stosunku Kościoła do religii niechrześcijańskich Nostra Aetate, w: Sobór Watykański II, Konstytucje, dekrety, deklaracje, Poznań 2002, s. 334-338.

Pikus T., Dialog religijny i jego obszary, „Warszawskie Studia Teologiczne” 20 (2007) 1, s. 229-242.

Polak M., Wychowanie do dialogu w katechezie młodzieży, „Studia Oecumenica” (2015) nr 15 , s. 413-426.

Różańska A., Religijność młodzieży a pluralistyczne społeczeństwo czeskie na początku XXI wieku, w: Edukacyjny potencjał religii, red. J. Bagrowicz, J. Horowski, Torun 2012, s. 315-336.

Rzym M., Trudna miłość. Katolicy wobec innych religii, „Misyjne Drogi” 34 (2016) nr 5/179, s. 54-55.

Sakowicz E., Edukacja w środowisku pluralizmu kulturowego i religijnego, w: Kulturamłodzież - edukacja, red. A. Popławska, L. M. Jakoniuk, Białystok 2008, s. 283-291.

Sakowicz E., Inny, ale nie obcy, cz. 1, „Oświata Mazowiecka” 10 (2010) nr 04/05, s. 22-24.

Sakowicz E., Inny, ale nie obcy, cz. 2, „Oświata Mazowiecka” 02 (2011) nr 01 (06), s. 21-23.

Sobór Watykański II, Konstytucje, dekrety, deklaracje, Poznań 2002.

Terlikowski T., Kalifat Europa, Kraków 2016. 